\title{
UDC 528.8
}

O. V. DREBOT ${ }^{1}$, O. V. ZUBOVA ${ }^{1}$, G. O. KHANT ${ }^{1}$, O. P. LUKIANENKO ${ }^{1}$, Ya. V. CHERNIAK ${ }^{1}$, O. I. SAVCHUK ${ }^{2}$

${ }^{1}$ Polissia National University, 7, Staryi boulevard, Zhytomyr, 10002, Ukraine, e-mail: o_drebot@ukr.net

${ }^{2}$ Institute for Agriculture of Polissia NAAS, 131, Kyiv highway, Zhytomyr, 10007, Ukraine, e-mail: grunt17isgp@gmail.com

https://doi.org/10.23939/istcgcap2020.91.051

\section{USAGE OF THE EARTH REMOTE SENSING DATA FOR THE ASSESSMENT OF SURFACE WATER AREA DYNAMICS ON THE BASIS OF IZIASLAV DISTRICT OF KHMELNYTSKY REGION, UKRAINE}

\begin{abstract}
It's been established that the problem of disappearing of open water body and the use of Earth remote sensing data for their monitoring is relevant and poorly covered in current Ukrainian and foreign scientific studies. The necessity of complex solution method has been also determined. The purpose of this paper is to study the dynamics of surface water area over a 45-year period (over a long period of time) across the Iziaslav district of Khmelnytsky on the basis of programming analysis of satellite imagery and the results from field surveys at key research sites. In this study, the freely available QGIS software was used to process satellite imagery. Field surveys (implied on the ground) took place at water bodies which disappeared in 1975, 1989, 2001, 2018. Multispectral LANDSAT imagery of remote sensing from 1975, 1984, 1989, 2001, 2018 were acquired and analyzed across the study region. Highquality images with cloud coverage of $<3 \%$ have been selected to support this research, as well as the quantity of all available images. Spectral analysis of the district territory has been performed with the help of special indicators of field surveys and QGIS software. The mapping of available water surface areas has been performed on the basis of the calculations of the spectral indices of NDWI and NDTI. Threshold values of the spectral indices for the classification of raster image components of the studied area are determined. Total changes in open water surface area between 1975 and 2018 have been quantified. It has been noted that total surface water area has decreased from 2933 hectares to 1499 hectares, a decrease of $48 \%$. The impact of warmer air temperatures on disappearing water bodies has been specified. The research has been conducted on the basis of long-term data with the help of modern methods of satellite imagery processing. The results of the given research can be used for further territory monitoring and further researches within other administrative-territorial units, in particular for making decisions on land use, developing strategic directions of overcoming environmental problems of land use, setting threshold indicators of land use in climate changing conditions, coastal and water bodies buffer zones monitoring.
\end{abstract}

Key words: Earth remote sensing, satellite image, index, map, Landsat, open water area.

\section{Introduction}

The problem of disappearing of small water bodies is quite serious in Ukraine. In 2014, there are 91 ponds with an area of 302 hectares within Iziaslav district [Khilchevskyi \& Hrebin, 2014]. According to the Department of Ecology of the Regional State Administration, there are 3733 rivers with a total length of $12880 \mathrm{~km}$ in 2017 . There are few lakes within the region, the largest lakes in the Khmelnytsky region, are the Sviate and Terebizh lake, with an area of 4.2 and 2.6 ha respectively. Artificial water bodies in total 2791 with 52 reservoirs [Kagalo, et al., 2016; Khmelnytsky Regional State Administration Department of Ecology and Natural Resources, 2017]. The number and area of water bodies are calculated according to cadastral data and do not take into account their availability and size in the area. It is known that the area of water bodies is constantly decreasing. According to the scientists, the main reasons for this are the following: climate change, pollution, siltation, irrational use of coastal areas. These factors also adversely affect the biodiversity of aquatic coenoses and coastal grasslands, which disrupt the agro-ecosystem sustainability. In addition, Ukraine's water resources are in a poor state because of pollution and do not meet quality standards for their consumption. Climate change problems and possible scenarios of adaptation to the changes in land structure draw an increasing attention. Ukraine's approval of the concept of implementing state policy in the field of climate change for the period up to 2030 calls for effective and inexpensive mechanisms for its implementation [Decree of the Cabinet of Ministers of Ukraine, 2017]. In this case, the use of remote sensing data 
of surface water area and its processing is critical. The most researched problem in the scientific literature related to the processing of space images in land use is the cartographic visualization of declining crop yields. The problem of water bodies under new climatic conditions has not been extensively researched yet in the works of modern scientists. However, there are some works on updating the geographical characteristics of rivers, erosion, deformations of river beds, siltation processes, water resources of individual objects monitoring [Cole et al., 2015; Drebot, et al., 2018; El-Asmar, et al., 2013; Mustafa, et al., 2012]. Thus, the main attention is paid to the ways of visualization of objects on cartographic images. They include the following methods: principal component method, tasseled cap (TC) transformation, spectral indices application method [Acharya et al., 2019; Crist, \& Cicone, 1984; Xu, 2006; Lacaux, et al., 2007], analysis of digital terrain models [Ali, \& Sridhar, 2019; Singh, et al., 2015; Burshtynska, et al., 2010; Shevchuk, et al., 2014]. Modern scientific literature does not contain the results of research on a complex solution of the problem of monitoring disappearing water surfaces. Water bodies require monitoring to assess potential changes in surface water area and their impacts on the environment and human health.

The purpose of the research is to study the dynamics of surface water area on the example of Iziaslav district of Khmelnytsky region with the use of different time Earth remote sensing data. Changes in surface water area are documented with Landsat satellite imagery obtained over a 45 -year period.

\section{Methodology}

Earth remote sensing data such as Landsat 1 (images of 1975), Landsat 4-7 (images of 1989, 2001), and Landsat 8 (images of 2018) obtained from the US Geological Survey's electronic archive $^{1}$, have been used to monitor changes in water areas. The images have been processed in open source geoinformation system (QGIS). The procedure for determining spectral indices for surface water monitoring included the following

1 US Geological Survey online-portal, www. Earthexplorer.usgs.gov steps: feasibility study for using Landsat images of different periods to observe the long-term dynamics of surface waters in water bodies; calculation of spectral indices of NDWI and NDTI according to the methodology [El-Asmar, et al., 2013; Lacaux, et al., 2007; McFeeters, 1996]; specifying pixel thresholds [Anand, et al., 2020; Kozlova, et al., 2018]. The spectral brightness of the green and neighboring infrared channels (1) have been used to calculate NDWI index. When map chart was drawn in 1975, the Normalized Difference Turbidity Index (2) of $\rho$ red and green ranges was used because satellite systems at that time lacked sensors of necessary range.

$$
\begin{gathered}
N D W I=\frac{\rho_{\text {Green }}-\rho_{\text {NIR }}}{\rho_{\text {Green }}+\rho_{N I R}} \\
N D T I=\frac{\rho_{\text {Red }}-\rho_{\text {Green }}}{\rho_{\text {Red }}+\rho_{\text {Green }}}
\end{gathered}
$$

Where $\rho_{\text {Green }}-$ is an average water reflection property of $0.5625 \mathrm{~nm}, \rho_{N I R}-0.865 \mathrm{~nm}, \rho_{\text {Red }}-$ $0.655 \mathrm{~nm}$.

Multispectral images have been used for the same time period with radiometric and geometric correction, which made the calculations possible. When selecting images we were guided by the absence of atmospheric phenomena. All the images used for the given research were received in July. In order to conduct a reliable spectral analysis of images and highlight the spectral characteristics of water surfaces, field studies were conducted. For this purpose, we used the data of our own field surveys form 12 small landlocked water bodies located in the east of Iziaslav district, and Netishyn reservoir. Subsequently, pixel classification of the raster image has been performed to specify threshold values of NDWI indices. The areas of the reservoirs were defined as total areas of the raster objects of the image, which correspond to the color range of the pixels. To determine the threshold values of NDWI and NDTI indices of different years, the optical properties of water bodies in the district under study were taken into account. Because the reflection of water in the formation of the image is determined not only by the water surface, but also by a number of other components, such as phytoplankton, suspended solids, yellow 
matter, oil emulsions, water pollution and others. The sites for field studies have been selected by the size of the surface of landlocked water bodies, as their visualization is provided by the resolution of the used images, which is $30 \mathrm{~m}$.

\section{The results of the research}

The territory of Iziaslav district is situated in the north of Khmelnytsky region and covers the parts of the forest-steppe zone and Male Polissia region. Geomorphological conditions of the district territory are identical to the natural-agricultural zoning and differ within the limits of Shepetivske Polissia and Horyn-Slutsk highland. The flat territories, with some slight height differences are the characteristic features of the natural conditions of Polissia area. The forest-steppe territory is more complicated in orographic terms: it is rugged by girders and river valleys. The beds of girdres and flood basins of river valleys are swampy. The steepness of slopes ranges from $3^{\circ}$ to $12-15^{\circ}$.

Long-term field surveys to monitor changes in the area of landlocked water bodies have been carried out within Ripky village council, where the experimental sites are located (Fig. 1).

This territory is situated within Polissia area of the district.

The comparative analysis of the available Landsat space images used in the calculations over different years indicates that there are enough highquality images used in monitoring (Table 1). The image of 1975 was used with a resolution of $60 \mathrm{~m}$, while the images of 1989, 2001, 2010 and 2018 had a resolution of $30 \mathrm{~m}$ respectively. The coordinate system used in the given research is WGS-84. The images are radiometrically and geometrically corrected.

Table 1

Images charachteristics

\begin{tabular}{|c|c|c|c|}
\hline Years & $\begin{array}{c}\text { Number of } \\
\text { available } \\
\text { images }\end{array}$ & $\begin{array}{c}\text { Number of } \\
\text { images } \\
\text { under } \\
\text { research }\end{array}$ & $\begin{array}{c}\text { Number of } \\
\text { high-quality } \\
\text { images, cloud } \\
\text { coverage } \\
(<3 \%)\end{array}$ \\
\hline 1975 & 1 & 1 & 1 \\
\hline 1989 & 4 & 2 & 2 \\
\hline 2001 & 5 & 2 & 2 \\
\hline 2010 & 5 & 2 & 1 \\
\hline 2018 & 20 & 4 & 1 \\
\hline
\end{tabular}

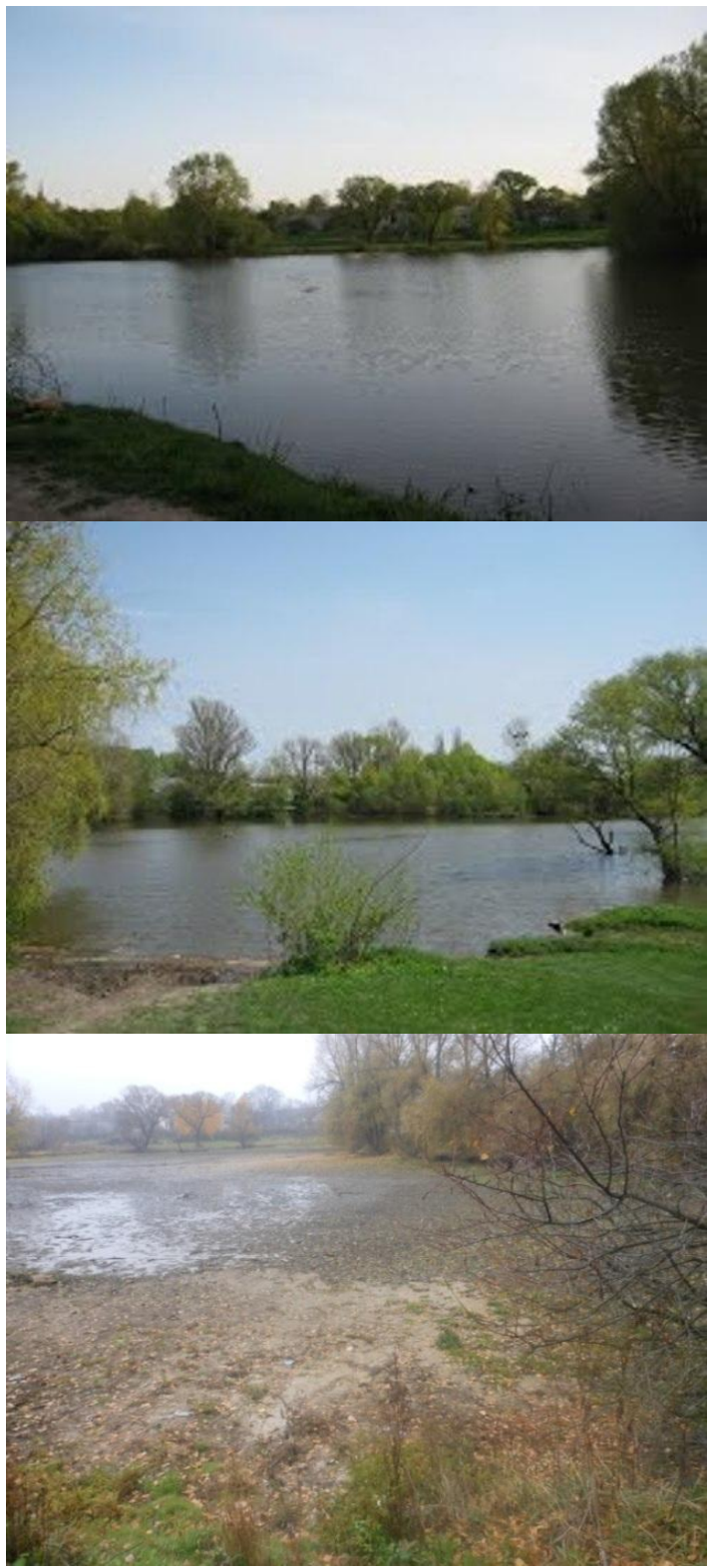

Fig. 1. Pond in Ripky village, spring 1975, 2014, 2018

As a result of superimposing field survey data on space images of those years, the threshold values of the respective indices have been established.

The map charts of spectral NDWI and NDTI indices show the areas of water surfaces as a set of pixels of one of the classes of threshold values within the raster. The presence of a water reservoir corresponds to the value of the indices: $>0.356$ (1975); 0.401 (1989); 0.494 (2001); 0.005 (2018). From the map given above, it can be observed that the area of water bodies has significantly decreased throughout the entire area (Fig. 2-5). 


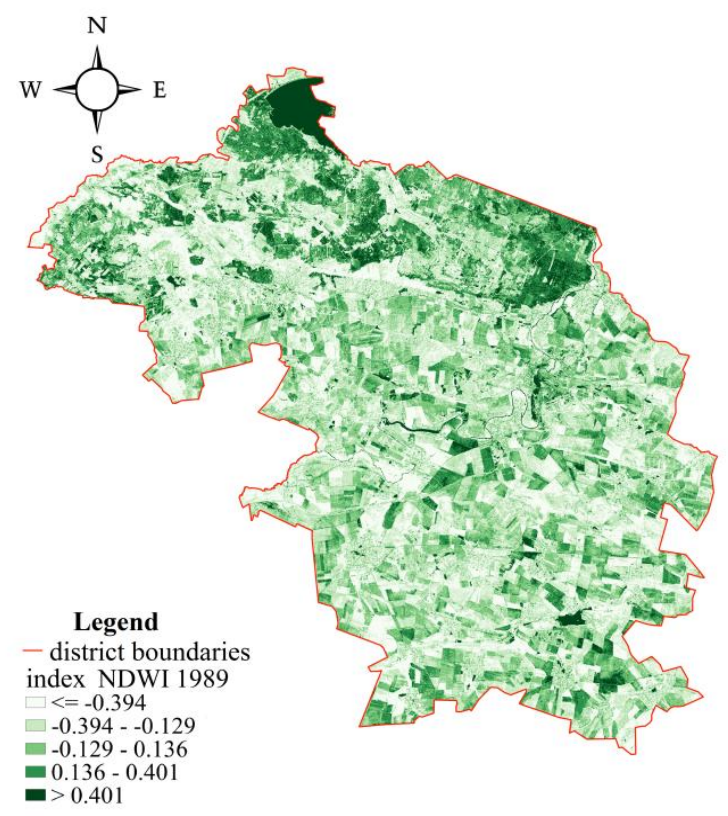

Scale

1:300 000

Fig. 2. Map chart of NDWI spectral index in 1989

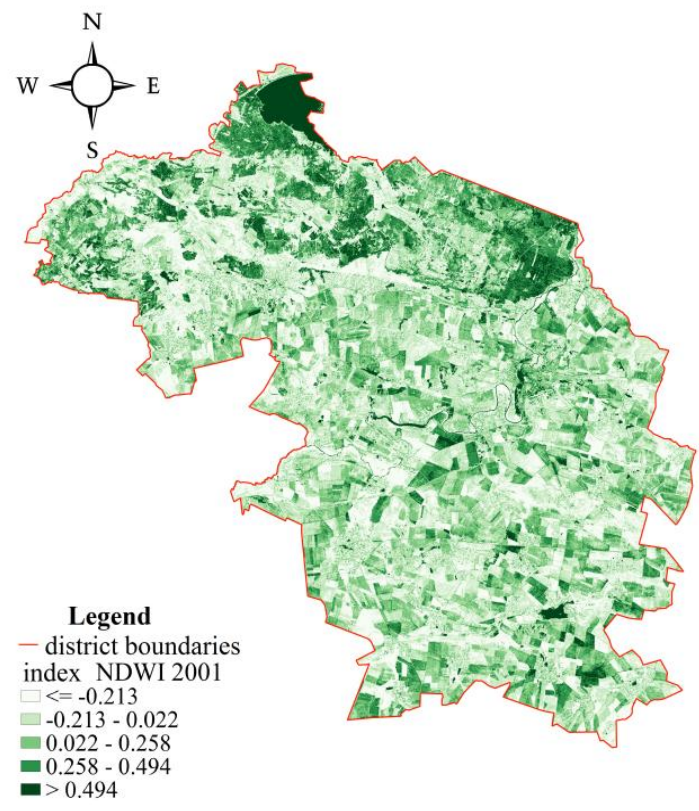

Scale

1:300 000

Fig. 3. Map chart of NDWI spectral index in 2001

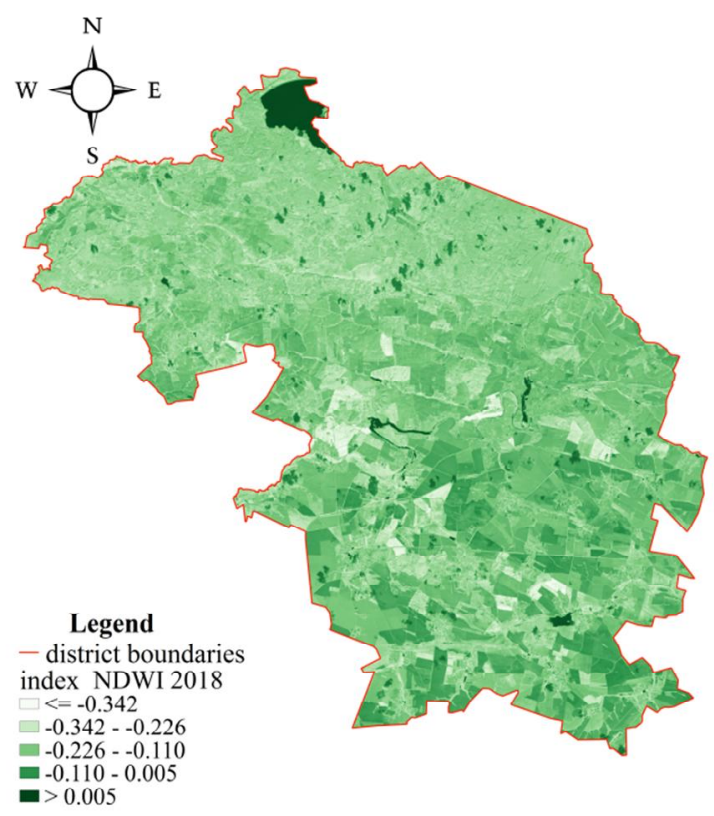

Scale

$1: 300000$

Fig. 4. Map chart of NDWI spectral index in 2018

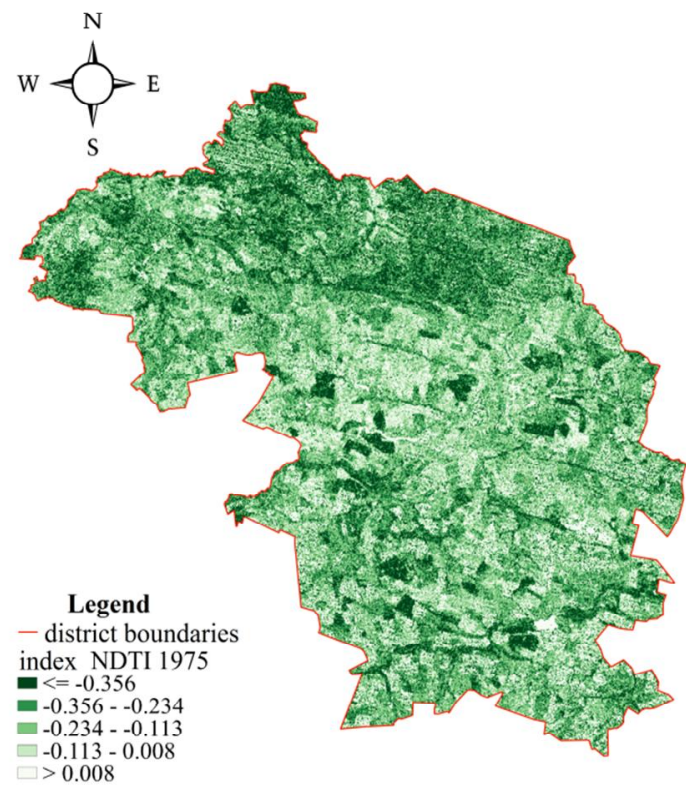

Scale

1:300 000

Fig. 5. Map chart of NDTI spectral index in 1975 
These results are emphasized by the dynamics of change of water body areas, calculated via indices analyzed in the pictures (Table 2). For the period of 1975-2018, the total area of water bodies decreased by 1433 ha, which is $48 \%$ of the area of surface water in 1975 within the area under study. The calculations of the area changes are not very indicative due to artificial pond made in 1984 with a total area of 1078 ha: the area decreased by 355 ha or by $12 \%$. In any case, the situation when water body areas decrease or even completely disappear within Iziaslav district of Khmelnytsky region is critical.

Table 2

Dynamics of changes of the areas covered by surface waters in the context of Iziaslav district

\begin{tabular}{|c|c|c|}
\hline Year & $\begin{array}{c}\text { S (Area) of water } \\
\text { body surface, ha }\end{array}$ & $\begin{array}{c}\text { Only S (Area) } \\
\text { of small water } \\
\text { bodies, ha }\end{array}$ \\
\hline 2018 & $2578^{*}$ & 1499 \\
\hline 2010 & $2582^{*}$ & 1504 \\
\hline 2001 & $2585^{*}$ & 1508 \\
\hline 1989 & $3252^{*}$ & 2173 \\
\hline $1975^{* *}$ & 2933 & 2933 \\
\hline
\end{tabular}

* The area includes a cooling pond of Khmelnytsky NPP made after 1984;

** Index NDTI is used for calculations.

If we visualize the data of the area changes, we will receive a diagram (Fig. 6). When predicting existing water bodies on the basis of calculated function, we have a considerable decrease in their area. If this trend of the curve is maintained, the area of closed water bodies will approach zero in 2063. The area will be reduced on average by 33 ha per year throughout the district.

The trend of meteorological data during the period of study indicates an increase of temperature (Fig. 7). As it can be seen from the diagram, the curve determination coefficient indicates adequate performance of temperature rise model within the time frames under study.

General relation between the temperature regime change and water body area decrease is observed, see Fig. 8 [Bulygina, et al., 2020]. The coefficient of determination and multiple correlation is 0.53 and 0.73 , respectively, which emphasizes the effect of air temperature on changes of water body areas. Thus, with the increase of the average temperature by $4^{\circ}$ in July for the period of 43 years the water body areas decreased by 1499 ha within the territory under research.

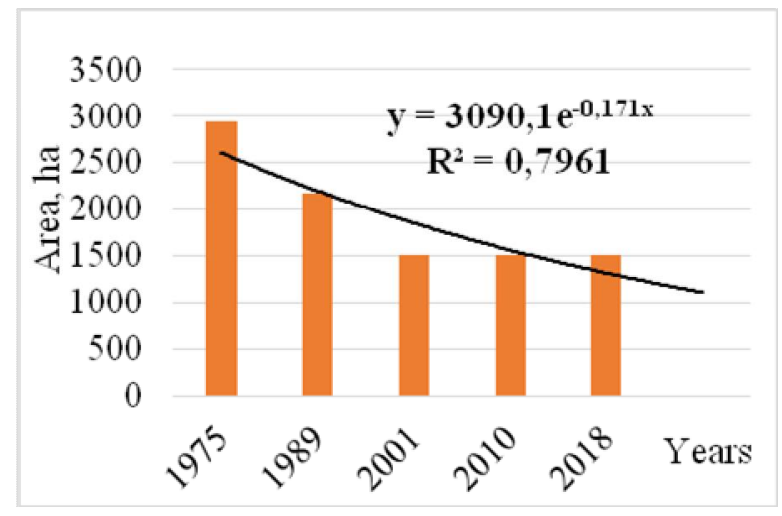

Fig. 6. Diagram of water area decrease for the period of $1975-2018$

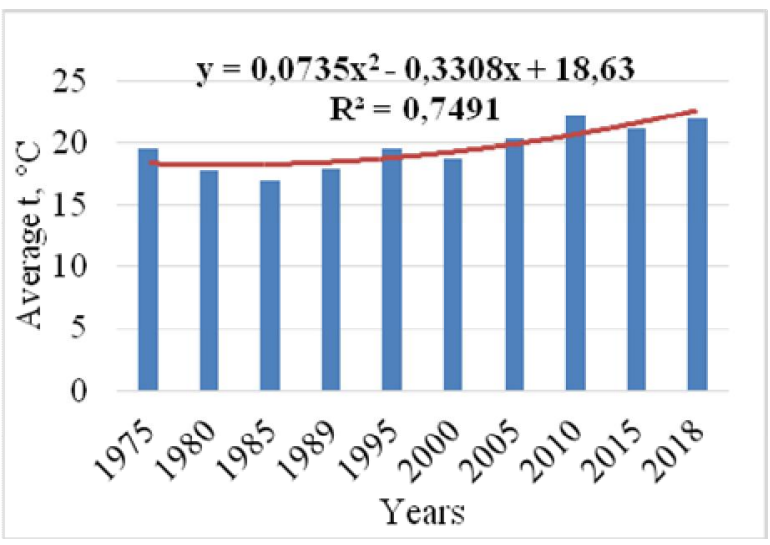

Fig. 7. Diagram of the average temperature increase in the region during the period under study

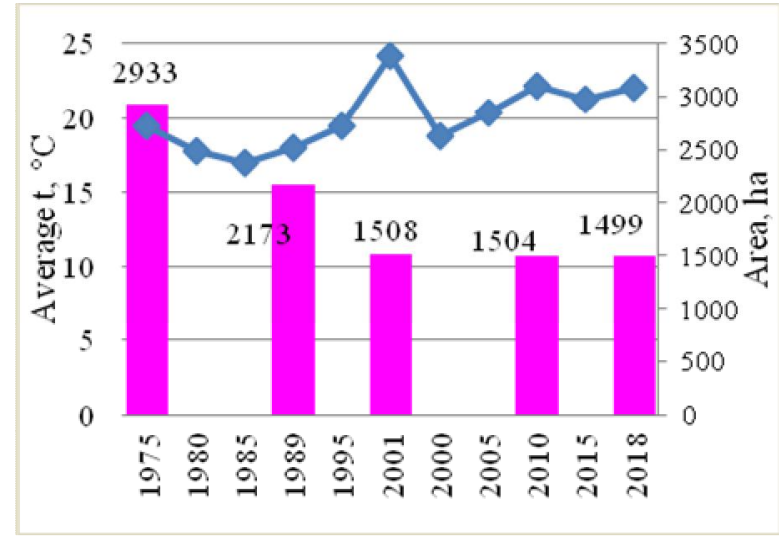

Fig. 8. Relation between surface landlocked water bodies decrease and air temperature changes 


\section{Scientific novelty and practical significance}

The given research represent the results of water area monitoring in the administrative district and are based on modern methods of the Earth remote sensing and programming analysis of space images (satellite imagery). Long-lasting field surveys of key research sites have been used to achieve the investigation results. The detailed description of space images regarding the possibility of their use is made. The results obtained give the prospects for further research, which can be divided into several areas. The development of methodological approaches to the analysis of cartographic raster materials of remote monitoring products and improvement of existing methods are particularly interesting. These results are also important to determine the strategy for developing a land use system under the conditions of climate change. for:

In particular, the given data can also be used

- making decisions on the use of land resources,

- setting the boundaries of the territories with the highest indicator of water bodies decrease within the area under study;

- development of directions and methodology of restoration of the territories undergoing landscape changes;

- making offers on climate change and irrational land use mitigation;

- setting extreme land-use indicators under the conditions of climate change;

- setting the boundaries of coastal buffer and protective zones around water bodies;

- monitoring changes in plant biodiversity within the areas under protection.

\section{Conclusions}

The results of the conducted researches prove that the water body area within Iziaslav district of Khmelnytsky region has been reduced from 2933 ha to 1499 ha, or by $48 \%$ without taking into account the area of the artificially made pond of Khmelnytsky NPP. This is evident from extensive temporal analysis of seven space images (the images show the changes in the water body area for the period of 43 years) in QGIS software with a resolution from $60 \mathrm{~m}$ to $30 \mathrm{~m}$. These studies are possible only by using field surveys of the territory and specifying the key points in raster space images which correspond to the location of the investigated sites (in the field). The change of water bodies monitoring, which is based on the gradation of the threshold values of NDWI, MNDWI and NDTI indices and automatic calculation of the area using software functions, proves that the situation with the water body area decrease is serious in the area under study. The increase in temperature, which had been observed from 1975 to 2018, coincided with the inverse dependency ratio of changes in the water bodies area. This is confirmed by relation between the air temperature change and water body area decrease. The results of research prove that, while maintaining the tendency of changing of water body area, this indicator can reduce to zero level, which may lead to complicated environmental consequences in the region. This implies the need to develop methodological and strategic approaches to solve this problem. The research also requires a more detailed study of the terrain conditions and the relationship between geomorphological conditions, groundwater and surface water. The research also proves the possibility of using the Earth remote sensing techniques and data interpolation within the region.

\section{REFERENCES}

Acharya, T. D., Subedi, A., \& Lee, D. H. (2018). Evaluation of water indices for surface water extraction in a Landsat 8 scene of Nepal. Sensors, 18(8), 2580. DOI: $10.3390 / \mathrm{s} 18082580$. Retrieved from https://www.ncbi.nlm.nih.gov/pmc/articles/PMC61118 78/ (Accessed: 01.10.2019).

Ali, S. A., \& Sridhar, V. (2019). Deriving the Reservoir Conditions for Better Water Resource Management Using Satellite-Based Earth Observations in the Lower Mekong River Basin. Remote Sensing, 11(23), 2872.

Anand, A., Krishnan, P., Kantharajan, G., \& Babu, D. E. (2020). Assessing the water spread area available for fish culture and fish production potential in inland lentic waterbodies using remote sensing: A case study from Chhattisgarh State, India. Remote Sensing Applications: Society and Environment, 17, p. 13. DOI: 10.1016/j.rsase.2019.100273. Retrieved from http://www.sciencedirect.com/science/article/pii/S2352 938519301272 (Accessed: 04.12.2019).

Bulygina, O. N., Razuvaev, V. N., \& Aleksandrova, T. M. Description of the data array of daily air temperature and precipitation at meteorological stations in Russia and in the former USSR (TTTR). 
(in Russian). Retrieved from http://meteo.ru/data/ 162-temperature-precipitation\#описание-массиваданных. (Accessed: 29.01.2020).

Burshtynska, Kh., Malanii, O., \& Shevchuk, V. (2010). Monitoring of deformation processes of the river beds. Modern achievements of geodetic science and production, 1(19), 216-226. UDK 528.92. (in Ukrainian).

Cole, C. J., Friesen, B. A., Wilson, E. M., Wilds, S. R., \& Noble, S. M. (2015). Use of satellite images to determine surface-water cover during the flood event of September 13, 2013, in Lyons and western Longmont, Colorado (No. 2015-1042). US Geological Survey. DOI: 10.3133/ofr20151042/. Retrieved from https://pubs.er.usgs.gov/publication/ ofr20151042 (Accessed: 28.11.2019).

Crist, E. P., \& Cicone, R. C. (1984). A physically-based transformation of Thematic Mapper data - The TM Tasseled Cap. IEEE Transactions on Geoscience and Remote sensing, (3), 256-263. DOI: 10.1109/TGRS.1984.350619. Retrieved from https://ieeexplore.ieee.org/document/4157507 (Accessed: 05.12.2019).

Decree of the Cabinet of Ministers of Ukraine (2017). On Approving the Concept of State Climate Change Policy Implementation until 2030 of 6 December 2017 \# 878-p. Uryadovij portal. (in Ukrainian). Retrieved from https://www.kmu.gov.ua/npas/ 249573705 . (Accessed: 21.12.2019).

Drebot, O., Kudryk, A. \& Lukianenko O. (2018). Methodological framework for data generation in a GIS-environment during agricultural land area management based on the landscape approach. Geodesy, Cartography and Aeriel Photography, 87, 58-64. DOI: 10.23939/istcgcap2018.01.058.

El-Asmar, H. M., Hereher, M. E., \& El Kafrawy, S. B. (2013). Surface area change detection of the Burullus Lagoon, North of the Nile Delta, Egypt, using water indices: A remote sensing approach. The Egyptian Journal of Remote Sensing and Space Science, 16(1), 119-123. DOI: 10.1016/j.ejrs.2013.04.004

Kagalo, O. O. et al. (2016). Regional scheme of ecological network formation of Khmelnytsky region. Institute of Ecology of the Carpathians NASU. Lviv-Khmelnytskyi. 71. (in Ukrainian).

Khilchevskyi V. K., Hrebin, V. V. (2014). Water Fund of Ukraine: artificial reservoirs $\square$ reservoirs and ponds: a guide. Kyiv: Interperes LTD. 164 p. ISBN 978-965-098-2
Khmelnytskyi Regional State Administration Department of Ecology and Natural Resources. (2017). Environmental condition of Khmelnytskyi region in 2016. Khmelnytskyi. (in Ukrainian). Retrieved from https://menr.gov.ua/files/docs/ Reg.report/Національна\%20доповідь\%20Хмельниць ка\%202016\%20piк.pdf. (Accessed: 14.10.2019).

Kozlova, M. V., Tursunova, G. Sh., Gorelic, O. V., \& Zemlyanov, I. V. (2018). The use of remote sensing data for studying tundra phytocenoses the example of the rivers' water-protection zones of the Nenets Autonomous District. Ecosystems: ecology and dynamics, 2(1). P. 92-110. DOI: 10.24411/25422006-2017-10005 (in Russian).

Lacaux, J. P., Tourre, Y. M., Vignolles, C., Ndione, J. A., \& Lafaye, M. (2007). Classification of ponds from high-spatial resolution remote sensing: Application to Rift Valley Fever epidemics in Senegal. Remote Sensing of Environment, 106(1), 66-74. DOI: 10.1016/j.rse.2006.07.012

McFeeters, S. K. (1996). The use of the Normalized Difference Water Index (NDWI) in the delineation of open water features. International journal of remote sensing, 17(7), 1425-1432. DOI: $10.1080 / 01431169608948714$.

Mustafa, Y. M., Amin, M. S. M., Lee, T. S., \& Shariff, A. R. M. (2012). Evaluation of land development impact on a tropical watershed hydrology using remote sensing and GIS. Journal of spatial hydrology, 5(2).

Shevchuk, S. A., Vyshnevskyi, V. I., \& Babii, P. O. (2014). Specification of hydrographic characteristics of rivers using remote sensing techniques. Bulletin of geodesy and cartography, 5(92), 29-32. UDK 556.5.08 + 556.51. (in Ukrainian).

Singh, K. V., Setia, R., Sahoo, S., Prasad, A., \& Pateriya, B. (2015). Evaluation of NDWI and MNDWI for assessment of waterlogging by integrating digital elevation model and groundwater level. Geocarto International, 30(6), 650-661. DOI: 10.1080/10106049.2014.965757

$\mathrm{Xu}$, H. (2006). Modification of normalized difference water index (NDWI) to enhance open water features in remotely sensed imagery. International journal of remote sensing, 27(14), 3025-3033. DOI: $10.1080 / 014311606005891$ 


\author{
О. В. ДРЕБОТ ${ }^{1}$,О. В. ЗУБОВА ${ }^{1}$, Г. О. ХАНТ ${ }^{1}$, О. П. ЛУК' ЯНЕНКО ${ }^{1}$, Я. В.ЧЕРНЯК ${ }^{1}$, О. І. САВЧУК ${ }^{2}$ \\ ${ }^{1}$ Житомирський національний агроекологічний університет, Старий бульвар, 7, Житомир, 10002, Україна, ел. пошта: \\ o_drebot@ukr.net \\ ${ }^{2}$ Інститут сільського господарства Полісся НААНУ, вул. Київське шосе, 131, Житомир, 10007, Україна, ел. пошта: \\ grunt17isgp@gmail.com
}

\title{
ВИКОРИСТАННЯ ДАНИХ ДИСТАНЦЙНОГО ЗОНДУВАННЯ ЗЕМЛІ ДЛЯ ОЦІККИ ДИНАМІКИ ПЛОЩ ПОВЕРХНЕВИХ ВОД НА ПРИКЛАДІ ІЗЯСЛАВСЬКОГО РАЙОНУ ХМЕЛЬНИЦЬКОЇ ОБЛАСТІ
}

Встановлено, що проблема зникнення відкритих водойм та використання даних дистанційного зондування землі для їх моніторингу $є$ актуальною та слабко висвітленою у сучасній вітчизняній та зарубіжній науковій літературі. Також, визначено необхідність комплексного методичного підходу її вирішення. Метою досліджень $є$ вивчення динаміки площ поверхневих вод протягом тривалого періоду часу в межах Ізяславського району Хмельницької області на основі програмного аналізу космічних знімків та результатів натурних обстежень ключових дослідних ділянок. Використано методику обробки растрових космічних знімків за допомогою програмного забезпечення QGIS. Виконано геоморфологічну характеристику Ізяславського району. Встановлено, що територія дослідження ділиться на дві частини: рівнинну 3 незначним перепадом висот та більш складну в орографічному відношенні зі складним рельєфом, великою кількістю ярів і балок, крутими схилами до $15^{\circ}$. Проведено обстеження в натурі (на місцевості) зниклих водойм станом на 1975, 1989, 2001, 2018 роки. Виконано збір та аналіз багатоспектральних знімків дистанційного зондування землі супутником Landsat станом на 1975, 1984, 1989, 2001, 2018 роки в межах досліджуваної території. Встановлено кількість доступних знімків, кількість знімків придатних до використання для дослідження, а також, кількість якісних знімків 3 хмарністю $<3 \%$. Виконано спектральний аналіз території району за допомогою встановлених показників натурних обстежень та програмного забезпечення QGIS. Ha основі розрахунків спектральних індексів NDWI та NDTI сформовано картосхеми, за якими були отримані наявні площі водних поверхонь. Встановлено порогові значення спектральних індексів для класифікації складових растрового зображення досліджуваної території. Вивчено зміну площ поверхневих замкнутих водних об'єктів протягом 1975 - 2018 років. Визначено, що загальна площа водного плеса водних об'єктів зменшилась 3 2933,1123 га до 1499,7349 га, на 48 \%. Встановлено залежність впливу температурного фактору на площу поверхневих вод. Дослідження було виконане на основі багаторічних даних за допомогою сучасних методів обробки космічних знімків. Представлені результати дослідження можуть бути використані для подальшого моніторингу території та розширення досліджень в межах інших адміністративно-територіальних одиниць, зокрема для формуванні рішень щодо використання земельного ресурсу, розробки стратегічних напрямків подолання екологічних проблем землекористування, встановлення критичних індикаторів землекористування в умовах змін клімату, моніторингу стану прибережних захисних смуг та охоронних зон водних об'єктів.

Ключові слова: дистанційне зондування Землі, супутниковий знімок, індекс, картосхема, Landsat, площа водойм.

Received 02.03.2020 